\title{
Use of packing equipment efficiency as an estimate of the overall plant effectiveness and as a tool to improve financial results of a food-processing unit
} Uso da eficiência do equipamento de envase como estimativa da eficiência global de tiragem e como ferramenta para melhorar os resultados financeiros de uma unidade de processamento de alimentos

\author{
José Boaventura Magalhães Rodrigues ${ }^{1 *}$, Antonio Carlos Dantas Cabral ${ }^{2}$ \\ ${ }^{1}$ DuPont do Brasil S.A., Packaging \& Industrial Polymers, Barueri/SP - Brazil \\ 2Instituto Mauá de Tecnologia, Production Engineering, São Caetano do Sul/SP - Brazil
}

\section{${ }^{*}$ Corresponding Author}

José Boaventura Magalhães Rodrigues, DuPont do Brasil S. A., Packaging \& Industrial Polymers, Al. Itapecuru, 506, CEP: 05464-080, Barueri/ SP - Brazil, e-mail: jose.boaventura@dupont.com

Cite as: Use of packing equipment efficiency as an estimate of the overall plant effectiveness and as a tool to improve financial results of a food-processing unit. Braz. J. Food Technol., v. 20, e2016068, 2017

Received: June 20, 2016; Accepted: Apr. 05, 2017

\section{Abstract}

Although Overall Equipment Effectiveness - OEE has been proven a useful tool to measure the efficiency of a single piece of equipment in a food processing plant it is possible to expand its concept to assess the performance of a whole production line assembled in series. This applies to the special case that all pieces of equipment are programmed to run at similar throughput of the system's constraint. Such procedure has the advantage to allow for simpler data collection to support operations improvement strategy. This article presents an approach towards continuous improvement adapted for food processing industries that have limited budget and human resources to install and run complex automated data collection and computing systems. It proposes the use of data collected from the packing line to mimic the whole unit's efficiency and suggests a heuristic method based on the geometric properties of OEE to define what parameters shall be targeted to plot an improvement plan. In addition, it is shown how OEE correlates with earnings, allowing for the calculation of the impact of continuous process improvement to business results. The analysis of data collected in a commercial food processing unit made possible: (i) the identification of the major causes of efficiency loss by assessing the performance of packing equipment; (ii) the definition of an improvement strategy to elevate OEE from $53.9 \%$ to $74.1 \%$ and; (iii) the estimate that by implementing such strategy an increase of $88 \%$ on net income is attained.

Keywords: Overall Equipment Effectiveness - OEE; Total Productive Maintenance - TPM; Continuous improvement; Food packing line efficiency.

\section{Resumo}

Apesar de a Eficiência Global dos Equipamentos - OEE ser uma ferramenta comprovadamente útil para medir a eficiência de um único equipamento em uma planta de processamento de alimentos, é possível expandir os seus conceitos para avaliar o desempenho de uma linha de produção em série. Isso se aplica para o caso especial em que todos os equipamentos são programados para operar com a mesma tiragem da restrição do sistema. Tal procedimento possibilita uma coleta simplificada de dados para suportar uma estratégia de melhoria das operações. Este artigo apresenta uma abordagem de melhoria contínua, adaptada para as indústrias de processamento de alimentos que contam com orçamento e recursos humanos limitados para implementar sistemas complexos de coleta automatizada e computação de dados. São propostos o uso de dados coletados na linha de envase para simular a eficiência de toda a unidade e um método heurístico, baseado nas propriedades geométricas da OEE, para identificar quais parâmetros devem ser considerados ao definir um plano de melhoria. Adicionalmente, demonstra-se como a OEE se correlaciona com a margem operacional, permitindo calcular o impacto do processo de melhoria contínua nos resultados do negócio. A análise dos dados coletados 
Use of packing equipment efficiency as an estimate of the overall plant effectiveness and as a tool to improve financial results of a food-processing unit

Rodrigues, J. B. M.; Cabral, A. C. D.

em uma unidade comercial de processamento de alimentos possibilitou: (i) identificar as principais causas de perdas de eficiência, analisando-se o desempenho do equipamento de envase; (ii) definir uma estratégia para elevar a OEE de $53,9 \%$ para $74,1 \%$ e; (iii) estimar que a implementação de tal estratégia resulta em um incremento de $88 \%$ na margem operacional do negócio.

Palavras-chave: Eficiência Global dos Equipamentos - OEE; Manutenção Produtiva Total - TPM; Melhoria contínua; Eficiência da linha de envase de alimentos.

\section{Introduction}

The manufacturing concept known as Total Productive Maintenance (TPM) launched by Nakajima in the 1980s is based on interrelated concepts including: (i) focused improvement to reduce losses; (ii) autonomous maintenance carried out by operators; and (iii) people training and collaboration (ENAGHANI et al., 2009). TPM establishes Overall Equipment Effectiveness (OEE) as the key metric behind the efforts to continuously maximize equipment effectiveness by measuring the ratio between the actual amount of quality product leaving the unit, and the theoretical (maximum) amount of product the equipment is capable of producing along a given period of time. OEE combines the operation and maintenance planning of manufacturing equipment and the resources required to fulfill plant goals (COSTA; LIMA, 2002). It is appreciated as it is a simple and clear overall indicator and provides an aggregated measure (DE RON; ROODA, 2005) that clearly identifies causes of losses in manufacturing and allows the continuous monitoring of the most important factors influencing a system's performance.

OEE identifies and measures manufacturing losses; namely availability, performance, and quality losses. The concept is increasingly popular and has been widely used as a quantitative tool essential for measurement of productivity in semiconductor manufacture operations. Given its proven advantages, other industries have also embraced OEE to improve their asset utilization and customized the procedures to fit their particular industrial features and requirements (MUCHIRI; PINTELON, 2008).

OEE has been reported as an effective tool to monitor production process (CASTRO; ARAUJO, 2012) as well as increase production rate, improve quality of products and safety (TSAROUHAS, 2007) of food processing plants. Such scientific works demonstrate the applicability of OEE as an effective metric to manage productivity on food industry and corroborate with the findings of this research.

Moreover it is important to keep in mind that the ultimate goal of improving operation efficiency is to maximize financial results of the asset (HANSEN, 2006). For that matter this paper also focused on correlating OEE with earnings.

Notwithstanding its popularity, researchers point OEE fails to provide a foundation to assess the effectiveness of a whole unit. While investigating the overall efficiency of a production unit alternative indicators such as Overall Throughput Effectiveness (OTE) are suggested (BUSSO; MIYAKE, 2013).

Thorough calculation of the effectiveness of a production unit as described by Huang et al. (2002) can be performed using algorithms dealing with data obtained from automated data recorders from various pieces of equipment. Neither this approach seems to fit the capabilities of smaller and less resourceful companies nor having a massive data crunch implies the people responsible for managing and operating the unit are capable of interpreting and converting it into useful information to enhance the unit's effectiveness in a consistent fashion.

The existence of a simpler model, dealing with a few key inputs to identify the causes of major losses operating in the process would contribute to sustain a long term and continuous improvement program specially for those companies just initiating the process given it requires lower financial and human resources to be put in place and manage.

While equipment is interconnected in a production line the overall effectiveness is greatly impacted by factors beyond the equipment itself, including material flow along the process (DE RON; ROODA, 2005). Therefore OEE data collected from a single equipment shall be capable of signaling disturbances occurring locally as well as coming from other parts of the process.

Considering it is possible to appraise the overall effectiveness of a production unit just analyzing OEE data from one piece of equipment the question remains: which equipment should be selected to collect the data to represent the whole unit effectiveness?

The objective of this paper is to propose that the OEE of a single equipment can be used as an estimator of the effectiveness of the whole unit consisting of a series of pieces of equipment. More specifically this article debates how the analysis of OEE parameters of a packing line installed downstream in a food processing unit can be resourceful to assess the effectiveness of such a unit and define the boundaries in which this approximated approach can be regarded acceptable. The results obtained from one case study show how this approximation is valid. 
Use of packing equipment efficiency as an estimate of the overall plant effectiveness and as a tool to improve financial results of a food-processing unit

Rodrigues, J. B. M.; Cabral, A. C. D.

\section{Methods}

The classic definition of OEE calculated for a single equipment is given by Equation 1 where availability $(A)$ measures the effectiveness of maintaining tools in a condition capable of running, performance efficiency $(P)$ measures how effectively the equipment is utilized while running and rate of quality $(\mathrm{Q})$ measures the effectiveness of the manufacturing process to eliminate scrap, rework and yield loss (POMORSKI, 1997).

$\mathrm{OEE}=\mathrm{A} \times \mathrm{P} \times \mathrm{Q}$

According to Pomorski (1997) each of the three elements is calculated as in Equations 2, 3 and 4.

$\mathrm{A}=\frac{\text { Equipment Uptime }}{\text { TotalTime }}$

$\mathrm{P}=\frac{\frac{\mathrm{N}_{\text {prod }}}{\text { EquipmentUptime }}}{\frac{\mathrm{N}_{\max }}{\text { Productive Time }}}$

and, $Q=\frac{N_{\text {spec }}}{N_{\text {prod }}}$

Where: "Equipment Uptime" is the timespan along when there is output from the equipment, "Total Time" the period the equipment is planned to be running, $N_{\text {prod }}$ the total number of units produced along the uptime, $\left(\frac{\mathrm{N}_{\max }}{\text { ProductiveTime }}\right)=\overline{\mathrm{R}}_{\max }$ is the optimum output ratio (units/ time) the equipment is designed to achieve and $N_{\text {spec }}$ the number of units produced that comply with specification (being $N_{\text {spec }} \leq N_{\text {prod }}$ ). Therefore, for any equipment, OEE is calculated by Equation 5 and $N_{\text {spec }}$ by Equation 6 .

OEE $=\frac{\mathrm{N}_{\text {spec }}}{\overline{\mathrm{R}}_{\text {max }} \cdot \text { TotalTime }}$

and,

$\mathrm{N}_{\mathrm{spec}}=\mathrm{OEE} \cdot \overline{\mathrm{R}}_{\max } \cdot$ Total Time
Given that the theoretical output ratio $\bar{R}_{\max }$ can be regarded constant along time for the equipment, it can also be related to the total time as shown in Equation 7.

$\overline{\mathrm{R}}_{\max }=\frac{\mathrm{N}_{\max }}{\text { Productive Time }}=\frac{\mathrm{N}_{\max }^{\prime}}{\text { Total Time }}$

Therefore OEE can be calculated along the Total Time by the proportion shown by Equation 8 .

OEE $=\frac{N_{\text {spec }}}{N_{\text {max }}^{\prime}}$

\subsection{Calculation of the overall effectiveness of a production unit}

For a production line consisting of a series of equipment (Figure 1) the OEE of the factory is given by Equation 9.

$\mathrm{OEE}_{(\mathrm{F})}=\frac{\mathrm{N}_{\mathrm{spec}(\mathrm{F})}}{\mathrm{N}_{\max (\mathrm{F})}^{\prime}}$

Where $\mathrm{N}_{\mathrm{spec}(\mathrm{F})}$ is the number of good units obtained along Total Time and $\mathrm{N}_{\max (\mathrm{F})}$ is the theoretical number of units that might be produced by the factory if it operates along Total Time at optimum rate without waste.

For each piece of equipment pertaining to a production unit assembled in series Equation 6 can be written as in Equation 10 (HUANG et al., 2003). Given the factory total time applies equally to all its components.

$\mathrm{N}_{\text {spec }(\mathrm{i})}=\mathrm{OEE}_{(\mathrm{i})} \cdot \overline{\mathrm{R}}_{\max (\mathrm{i})} \cdot$ Total Time $]_{\mathrm{i}=1,2, \ldots \mathrm{n}}$

Given the number of good finished product units produced by the factory is the number of in-spec units leaving the $\mathrm{n}^{\text {th }}$ equipment as calculated by Equation 11. Therefore the $\mathrm{OEE}_{(\mathrm{F})}$ can be calculated by Equation 12.

$\mathrm{N}_{\text {spec }(\mathrm{F})}=\mathrm{N}_{\mathrm{spec}(\mathrm{n})}=\mathrm{OEE}_{(\mathrm{n})} \cdot \overline{\mathrm{R}}_{\max (\mathrm{n})} \cdot$ Total Time

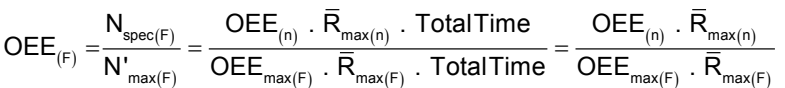

The maximum effectiveness of the factory OEE $\mathrm{max}_{\operatorname{ma}(\mathrm{F})}$ equals one $\left(O \mathrm{OE}_{\max (\mathrm{F})}=1\right)$. Considering the average production ratio along time for a series of equipment is given by the

Contour Region: Unit

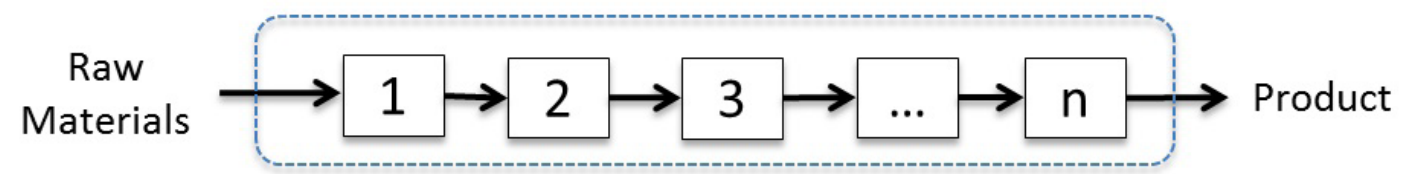

Figure 1. Production unit assembled in series. 
Use of packing equipment efficiency as an estimate of the overall plant effectiveness and as a tool to improve financial results of a food-processing unit

Rodrigues, J. B. M.; Cabral, A. C. D.

ratio of the slowest equipment in line $\bar{R}_{\text {máx(F) }}=\min \left\{\bar{R}_{\text {máx(i) }}\right\}$, then the OEE of the factory is calculated by Equation 13.

$\mathrm{OEE}_{(\mathrm{F})}=\frac{\mathrm{OEE}_{(\mathrm{n})} \cdot \overline{\mathrm{R}}_{\max (\mathrm{n})}}{1 \cdot \min \left\{\overline{\mathrm{R}}_{\max (\mathrm{i})}\right\}}$

For the special case where the throughput of all pieces of equipment in line is balanced - i.e. each equipment runs at the same throughput of the constraint and not at the individual theoretical (maximum) throughput, than the optimum operating ratio $\overline{\mathrm{R}}_{\text {máx(i) }}$ is similar for all equipment in the series along Total Time; meaning: $\left.\min \left\{\overline{\mathrm{R}}_{\text {máx(i) }}\right\}=\overline{\mathrm{R}}_{\text {máx(i) }}\right\rfloor_{\mathrm{i}=1,2, \ldots \mathrm{n}}=\overline{\mathrm{R}}_{\text {máx(n) }}$. Therefore the OEE of $\mathrm{n}^{\text {th }}$ equipment can be calculated by Equation 14 .

$\mathrm{OEE}_{(\mathrm{F})}=\frac{\mathrm{OEE}_{(\mathrm{n})} \cdot \overline{\mathrm{R}}_{\max (\mathrm{n})}}{\overline{\mathrm{R}}_{\max (\mathrm{n})}}=\mathrm{OEE}_{(\mathrm{n})}=\mathrm{A}_{(\mathrm{n})} \cdot \mathrm{P}_{(\mathrm{n})} \cdot \mathrm{Q}_{(\mathrm{n})}$

In conclusion for the special case where all pieces of equipment in a series are planned to operate along the same Total Time at the same pace the OEE of a factory can be calculated as the OEE of the last equipment assembled in the line.

Similarly if the line has a more complex assembly with equipment displaced in series and parallel as shown in Figure 2, the OEE of the factory can be approached as a line in series as the cells consisting of equipment in parallel can be reduced to a single operating unit. For the special case where: $\min \left\{\overline{\mathrm{R}}_{\max (\mathrm{i})}\right\}=\overline{\mathrm{R}}_{\max (\mathrm{i})}=\overline{\mathrm{R}}_{\max (3 \mathrm{p})}=\sum_{\mathrm{j}=1}^{\mathrm{m}} \overline{\mathrm{R}}_{\max (3 . \mathrm{j})}$ and all equipment is planned to run along the same Total Time the number of in-spec and maximum product units leaving the cell and its OEE are given by Equations 15, 16 and 17 respectively.

$$
\begin{aligned}
& \mathrm{N}_{\mathrm{spec}(3 p)}=\sum_{\mathrm{j}=1}^{\mathrm{m}} \mathrm{N}_{\mathrm{spec}(3 . \mathrm{j})}=\sum_{\mathrm{j}=1}^{\mathrm{m}}\left(\operatorname{OEE}_{(3 . \mathrm{j})} \cdot \overline{\mathrm{R}}_{\max (3 . \mathrm{j})} \cdot \text { TotalTime }\right) \\
& \mathrm{N}_{\max (3 p)}^{\prime}=\sum_{\mathrm{j}=1}^{\mathrm{m}} \mathrm{N}_{\max (3 . \mathrm{j})}^{\prime}=\sum_{\mathrm{j}=1}^{\mathrm{m}}\left(\overline{\mathrm{R}}_{\max (3 . \mathrm{j})} . \text { Total Time }\right) \\
& \operatorname{OEE}_{(3 p)}=\frac{N_{s p e c(3 p)}}{N_{\max (3 p)}^{\prime}}=\frac{\sum_{j=1}^{m}\left(\operatorname{OEE}_{(3 . j)} \cdot \bar{R}_{\max (3 . j)} \cdot \text { TotalTime }\right)}{\sum_{j=1}^{m}\left(\bar{R}_{\max (3 . j)} \cdot \text { TotalTime }\right)}= \\
& \frac{\sum_{j=1}^{m}\left(\operatorname{OEE}_{(3 . j)} \cdot \bar{R}_{\max (3 . j)}\right)}{\sum_{j=1}^{m}\left(\bar{R}_{\max (3 . j)}\right)}
\end{aligned}
$$

For this special case it is assumed that any disturbance that happens in any piece of equipment along the production line will affect the capacity of the last one in the series to fulfill its planned output. Therefore losses accounted for upstream will eventually result in losses downstream. These disturbances will be noticed and recorded while calculating the OEE of the $n^{\text {th }}$ equipment.

In a typical food processing plant the last equipment in the factory that has a fixed position and where a data collecting station can be placed is the packing line. Afterwards the finished product is moved to the storage facility to wait for shipping to customers. Therefore it is recommended to calculate the overall plant effectiveness of a food processing plant by measuring the OEE of the packing line.

Other heuristics to support the selection of the packing line is that the bottleneck tends to shift from one

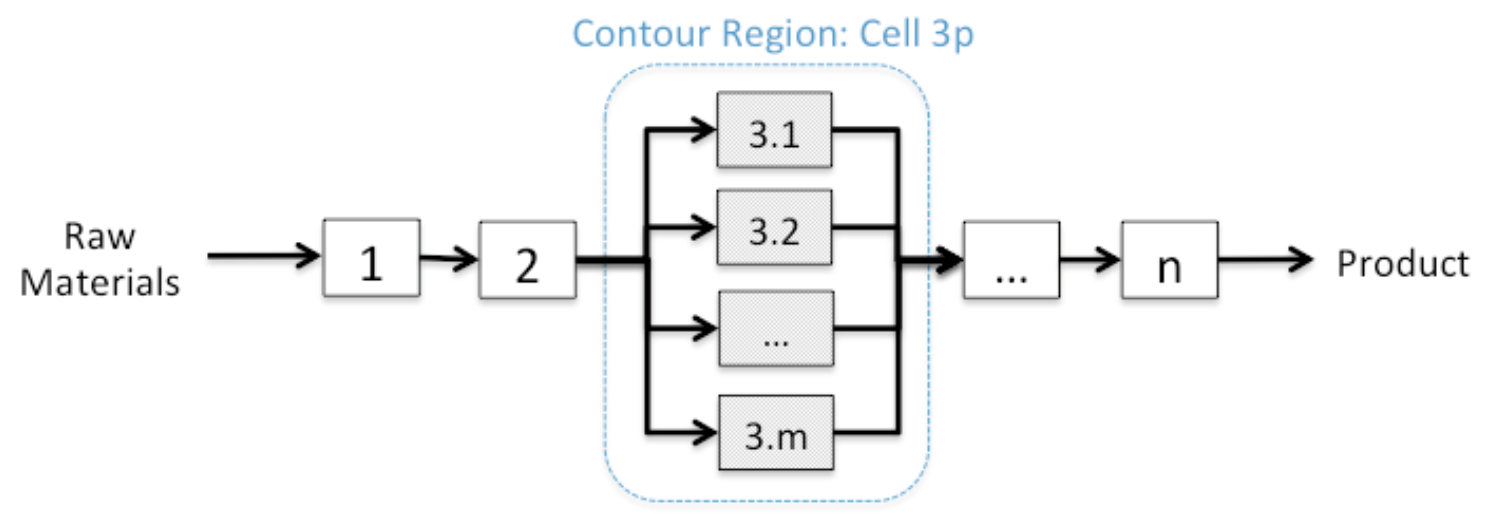

Contour Region: Unit

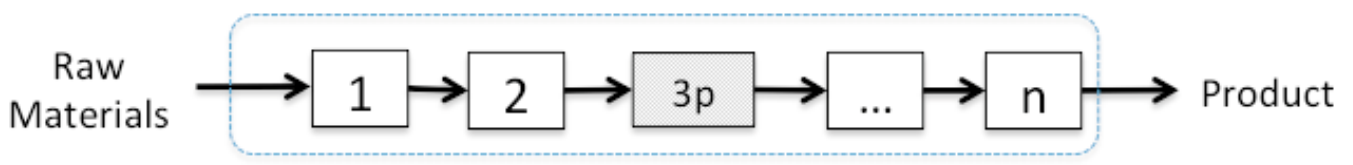

Figure 2. Production unit assembled in series and parallel. 
Use of packing equipment efficiency as an estimate of the overall plant effectiveness and as a tool to improve financial results of a food-processing unit

Rodrigues, J. B. M.; Cabral, A. C. D.

piece of equipment to another along time, so it would become tedious and possibly useless to keep chasing the bottleneck to install the data collection post. Another more mundane reason is that it is merely simpler to do so and start collecting data right away. After all OEE is about continuous improvement and if, for any reason, a better collecting point pops-up later the team can consider moving the data collection point elsewhere.

\subsection{Correlation of overall effectiveness and financial results}

In a general business context, net income $(\mathrm{NI})$ is defined as a company's total earnings (or profit). It is a measure of how profitable the company is over a period of time. Net income is calculated as revenue deducted from the cost of doing business (operating expenses), depreciation, interest and taxes as in Equation 18 (INVESTOPEDIA LIBRARY, 2015).

\section{$\mathrm{NI}=$ Revenue - operating expenses - \\ depreciation(DP) - interest (IR) - taxes (TX)}

Revenue (Rev) is the total income received from the sales and it can be represented by the number of product units sold times the average unit price of each unit $\left(\bar{\Phi}_{\text {un }}\right)$. Considering all units produced along Total Time $\left(\mathrm{N}_{\text {prod }}\right)$ are sold the revenue is given by:

$\operatorname{Rev}=\operatorname{Nprod} \times \overline{\$}_{\text {un }}$

$\mathrm{N}_{\text {prod }}$ is the sum of goods produced within specification and the off-spec goods ( $\mathrm{N}_{\text {prod }}=\mathrm{N}_{\text {spec }}+\mathrm{N}_{\text {off }}$ ). Being those goods sold respectively at prices $\$_{\text {spec }}$ and $\$_{\text {offi }}$, the revenue Equation 19 can be written as follows:

$\mathrm{Rev}=\mathrm{N}_{\mathrm{spec}} \times \$_{\text {spec }}+\mathrm{N}_{\text {off }} \times \$_{\text {off }}$

As normally off-spec goods are produced in much smaller amount $\left(\mathrm{N}_{\text {spec }}>>\mathrm{N}_{\text {off }}\right)$ and sold at a discount price, meaning $\left(\$_{\text {spec }}>\$_{\text {off }}\right)$ than $\left(N_{\text {spec }} \times \$_{\text {spec }}>>N_{\text {off }} \times \$_{\text {off }}\right)$. Though Equation 20 can be simplified as in Equation 21.

$\mathrm{Rev} \cong \mathrm{N}_{\text {spec }} \times \$_{\text {spec }}$

The operating expenses include cost of raw material and utilities required for the production of goods, wages and R\&D expenses. Those expenses are classified as variable cost (VC) or fixed cost ( $F C)$, resulting in: operatingexpenses $=\mathrm{VC}+\mathrm{FC}$. Therefore Equation 18 is rewritten as:

$$
\mathrm{NI}=\mathrm{N}_{\mathrm{spec}} \times \$_{\text {spec }}-[(\mathrm{VC}+\mathrm{FC})+\mathrm{DP}+\mathrm{IR}+\mathrm{TX}]
$$

Being VC proportional to the number of goods sold and considering taxes proportional to the net income and the other fixed expenses constant along Total Time $\left(\mathrm{FC}+\mathrm{DP}+\mathrm{IR}=\right.$ cte $\left.\left.\right|_{\mathrm{Tt}}=\mathrm{FE}\right)$ Equation 22 can be rewritten as:
$\mathrm{ni}(1+\mathrm{tx})=\mathrm{N}_{\mathrm{spec}}\left(\$_{\mathrm{spec}}-\mathrm{vc}\right)-\mathrm{FE}$

From Equations 6 and $7 \mathrm{~N}_{\text {spec }}=$ OEE. $\mathrm{N}_{\text {max }}^{\prime}$. Replacing $\mathrm{N}_{\text {spec }}$ in Equation 23 it is found that net income is given as in Equation 24.

$\mathrm{ni}=\left[\frac{\mathrm{N}_{\mathrm{max}}^{\prime} \cdot\left(\$_{\text {spec }}-\mathrm{vc}\right)}{(1+\mathrm{tx})}\right] \cdot \mathrm{OEE}-\left[\frac{\mathrm{FE}}{(1+\mathrm{tx})}\right]$

Considering that none of the parameters on coefficients $\left[\frac{\mathrm{N}_{\text {max }}^{\prime} \cdot\left(\$_{\text {spec }}-\mathrm{vc}\right)}{(1+\mathrm{tx})}=\alpha\right]$ and $\left[\frac{\mathrm{FE}}{(1+\mathrm{tx})}=\beta\right]$ vary significantly along Total Time one can assume the net income is a linear function of OEE as shown by Equation 25.

$\mathrm{ni}=\alpha . \mathrm{OEE}-\beta$

As shown on Figure 3 the power of OEE to improve net income is increased as coefficient $\alpha$ increases to $\alpha$ ' and coefficient $\beta$ to $\beta$ '. This is obtained as the theoretical number of units produced along Total Time $\left(\mathrm{N}_{\max }{ }\right)$ and the unit price $\left(\$_{\text {spec }}\right)$ increase and as the unit variable cost ( vc ) and the fixed expenses (FE) decrease.

\subsection{Using geometric properties of OEE to select what parameter to improve}

From Equation 1 the OEE indicator can be depicted as the volume of a cube with edges $A, P$ and $Q$. The minimum value of OEE is zero - that happens if at least one of the parameters $A, P$ or $Q$ is zero. The maximum OEE value is 1.0 for the case no losses are accounted for and all three parameters value 1.0.

OEE also relates with the geometric mean $\left(\bar{A}_{g}\right)$ of parameters A, P and $Q$ as shown below (Equations 26, 27).

$\bar{A}_{g}=\left(\prod_{a=1}^{n} a_{i}\right)^{1 / n}=\sqrt[n]{a_{1} \cdot a_{2} \cdot a_{3} \ldots a_{n}}$

$\overline{\mathrm{OEE}}_{g}=\sqrt[3]{\mathrm{A} \cdot \mathrm{P} \cdot \mathrm{Q}}=\sqrt[3]{\mathrm{OEE}}$

Similarly as for the geometric mean OEE is highly sensitive to variability among the three parameters. That property is of particular interest because along with high utilization, variability leads to larger cycle times for the batches (JACOBS et al., 2003). From the geometric mean properties it is expected that an incremental improvement to the parameter with smallest value shall cause greater impact on the resulting OEE.

As an example consider that data taken from a hypothetical equipment result in Availability, Performance and Quality parameters valuing respectively: $0.25,0.80$ and 0.90 . The OEE calculated from this set of data is 
Use of packing equipment efficiency as an estimate of the overall plant effectiveness and as a tool to improve financial results of a food-processing unit

Rodrigues, J. B. M.; Cabral, A. C. D.

shown in Equation 28. An improvement of 0.10 achieved in Availability (OEEa - Equation 29) result in greater gain than the same 0.10 improvement in Quality (OEEq - Equation 30).

This effect is also shown by the pictorial representation of geometric properties of these observations on Figure 4.

$\mathrm{OEE}=\mathrm{A} \times \mathrm{P} \times \mathrm{Q}=0.25 \times 0.80 \times 0.90=0.18$

OEEa $=(0.25+0.10) \times 0.80 \times 0.90=0.25$

OEEq $=0.25 \times 0.80 \times(0.90+0.10)=0.20$

Due to these features the team involved in the continuous process of improving OEE should prefer to focus their efforts to improve the parameter with the lowest value.

\section{Results and discussion}

To validate the calculations shown on session 2 a case study was conducted by collecting data from the packing unit along a four-month period in a soy processing plant located in Brazil. All data was collected manually by operators and recorded on preformatted paper sheets. The goals of this study were: (i) to measure major effectiveness losses; (ii) identify the root causes of those losses and; (iii) provide a quantitative analysis to help define a strategy to improve plant effectiveness.

\subsection{Case study: using OEE methodology to plot the improvement plan}

Along 88 days 721 events were recorded for the three shifts ( $A, B$ and $C$ ) operating the packing equipment. Along data collection period no deliberate improvement

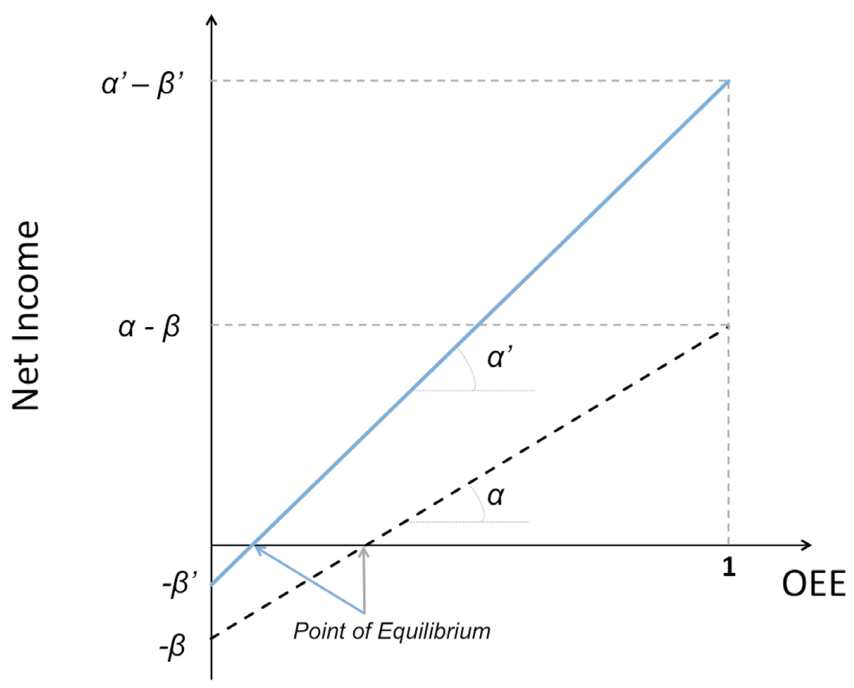

Figure 3. Correlation of net income and OEE.
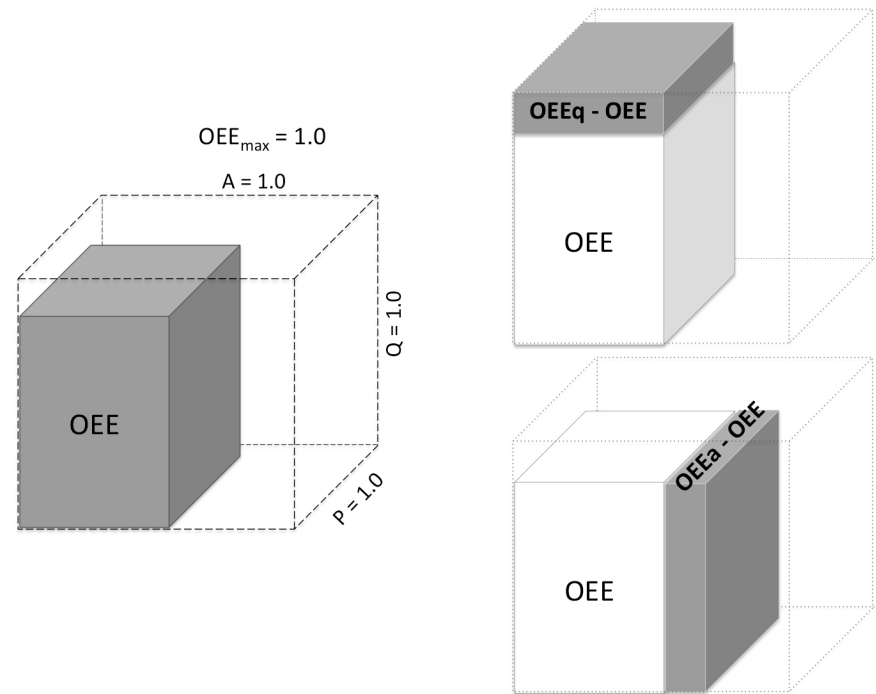

Figure 4. Geometric properties of OEE. 
Use of packing equipment efficiency as an estimate of the overall plant effectiveness and as a tool to improve financial results of a food-processing unit

Rodrigues, J. B. M.; Cabral, A. C. D.

has been implemented to the process. Figure 5 shows the calculated daily results for OEE and the OEE for each shift.

Figure 6 shows the results obtained for the consolidated monthly OEE for the unit and per shift. The 95\% confidence interval shows a wide dispersion of data as well as there is no significant difference in performance among the three shifts.

The analysis of parameters Availability, Performance and Quality (Figure 7) shows that monthly OEE was primarily affected by Availability losses while Performance and
MONTH 1

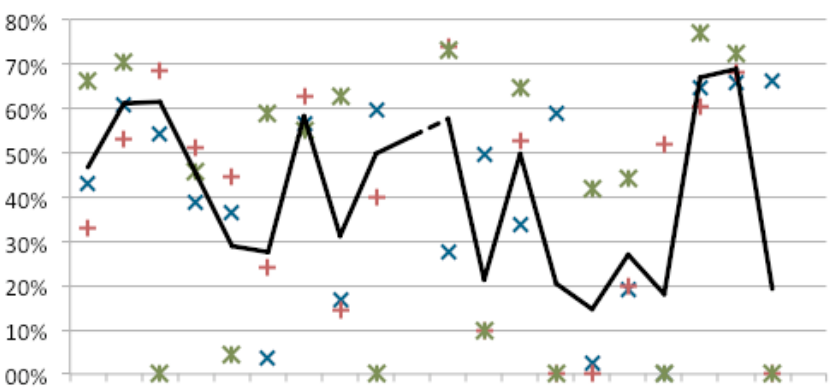

$11121314151617 \quad 1819202122 \quad 23 \quad 24 \quad 2526 \quad 27 \quad 28 \quad 2930 \quad 31$

$\times$ OEE Sft. $A+$ OEE Sft. B $\quad$ \& OEE Sft. C Daily OEE
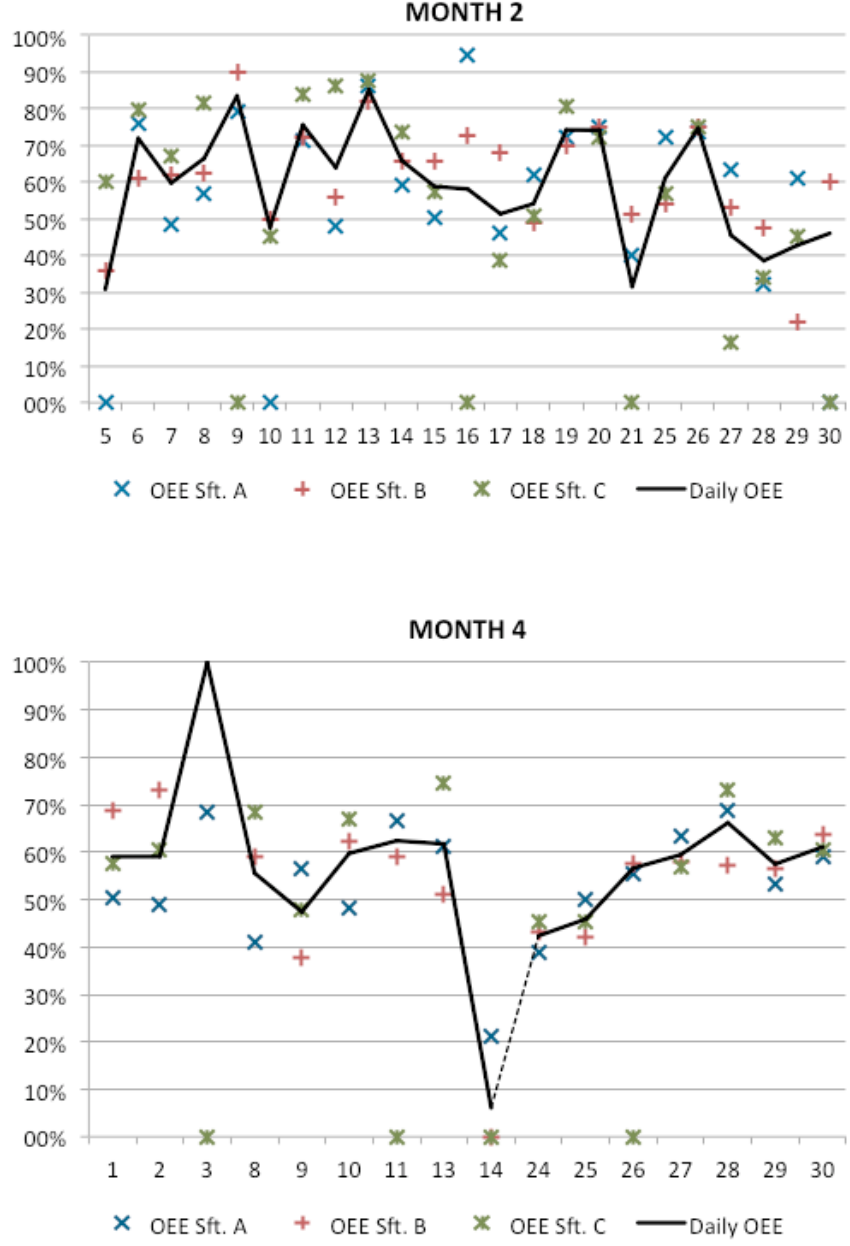

Figure 5. Daily OEE consolidated and per shift.

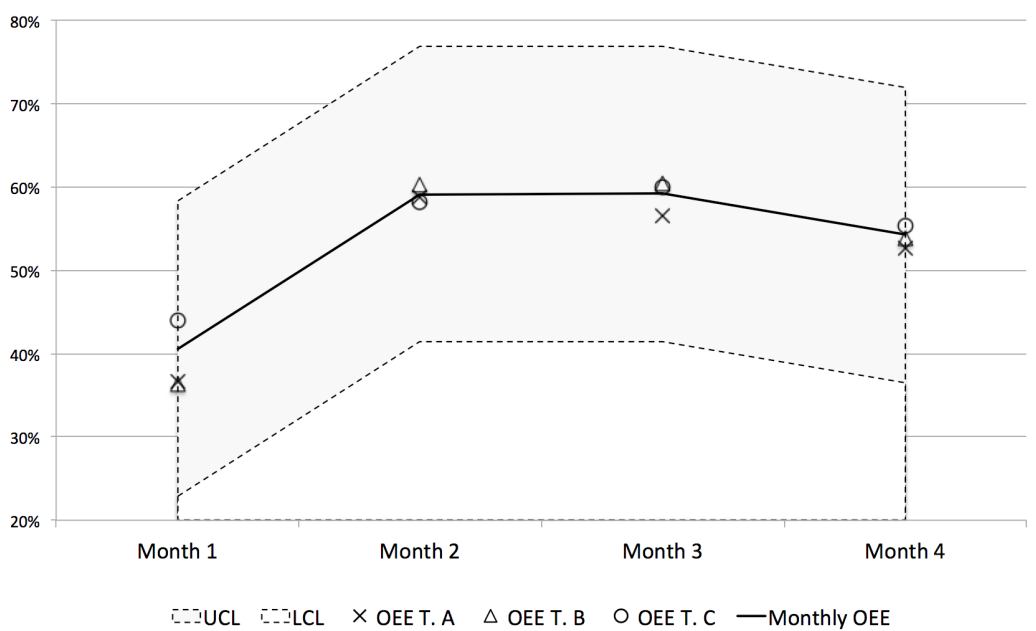

Figure 6. Monthly OEE per shift, consolidated OEE and 95\% confidence interval plot. 
Use of packing equipment efficiency as an estimate of the overall plant effectiveness and as a tool to improve financial results of a food-processing unit

Rodrigues, J. B. M.; Cabral, A. C. D.

Quality indexes stayed consistently above 95\%. For that reason a deeper analysis was made to identify the major losses associated with Availability - the primary target for continuous improvement.

Major Availability losses were categorized as: non-scheduled maintenance (29,010 min. - 58\% of Availability losses); packaging failure (11,079 min. - 22\%); lack of demand that are downstream losses (8,260 min. - 13\%) and; lack of product input to the packing line (952 min. - 2\%). The latter are packing line stoppages caused by losses in equipment upstream resulting in the interruption to the production flow (Figure 8).

The data analysis shows that $15 \%$ of Availability losses were not directly related to packing line failures. This observation validates the hypothesis that data collected at a single point in the process allows capturing losses that occurred either upstream or downstream the data collection station.

A deeper analysis of non-scheduled maintenance data (Figure 9) shows that major causes of packing equipment failure are related to: electrical failures (26\%), unscheduled operational (26\%) or mechanical (23\%) adjustments, worn parts or equipment breakdown (13\%) and automation failures (6\%).

In connection with the OEE analysis above, an action plan (Table 1) was proposed to improve the overall plant effectiveness, focusing on improving the packing operation performance.

Based on the expected improvement (existing OEE of $53.9 \%$ versus OEE of $74.1 \%$ for the proposed scenario) it is possible to estimate the financial benefit possibly achieved after the improvement plan is implemented. Figure 10

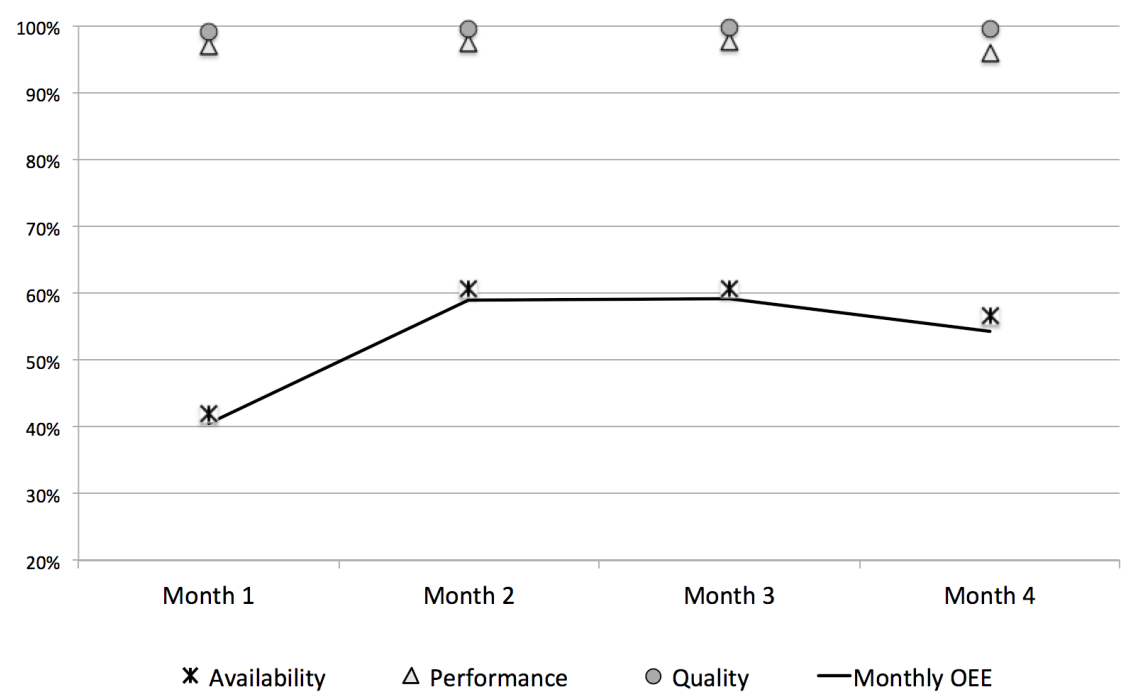

Figure 7. Monthly OEE, availability, performance and quality results.

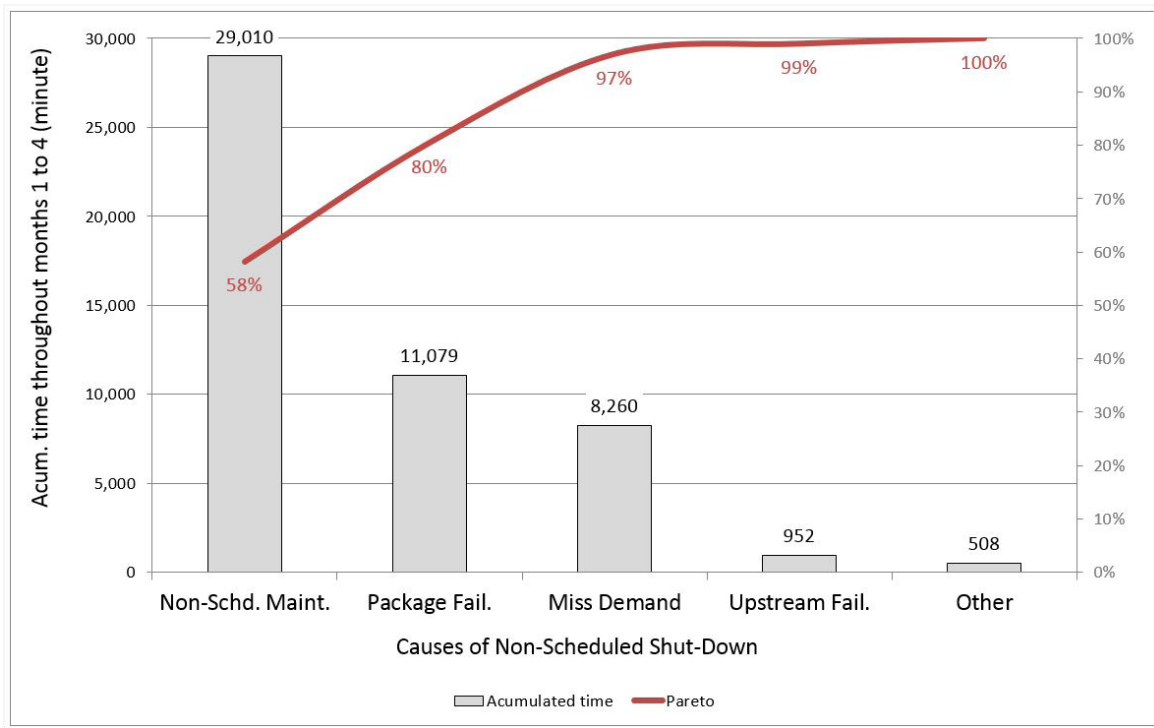

Figure 8. Causes of availability losses. 
Use of packing equipment efficiency as an estimate of the overall plant effectiveness and as a tool to improve financial results of a food-processing unit

Rodrigues, J. B. M.; Cabral, A. C. D.

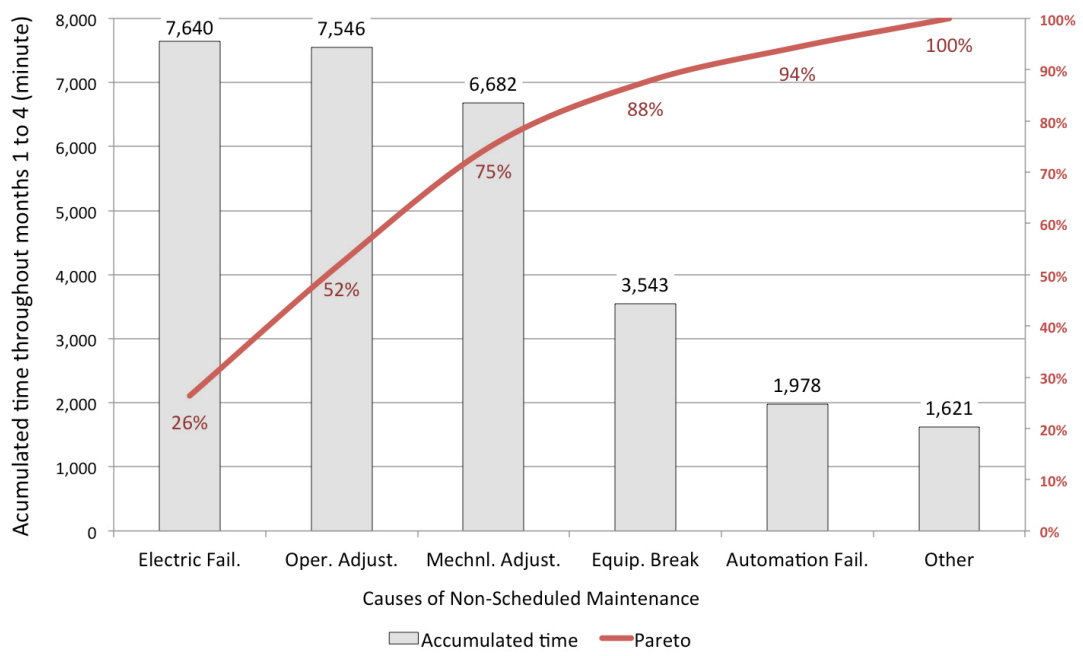

Figure 9. Causes of non-scheduled maintenance.

Table 1. OEE improvement plan.

\section{Strategy}

1. Reduce causes of non-scheduled maintenance stoppages (packing line)

2. Reduce frequency of adjustments needed to the packing equipment

3. Reduce packaging failure to comply with specified performance

\section{Action}

Desired effect

Schedule 2-hour preventive maintenance per shift per week (scheduled shut-down). All personnel accounted for (mechanics, electricians and operators).

Scrutinize root causes of unexpected stoppage related to automation and electric failures. Include action plan for preventive maintenance procedure.

Schedule 2-hour training and performance evaluation for each shift every week (coordinated by OEE specialists) to identify causes and review standard adjustment procedure.

Review packaging specification to reduce variability among suppliers and batches. Collaborate with packaging suppliers to help them comply with specification and reduce variability (operations, packaging engineering, procurement).
Reduce electrical, mechanical and automation failures by $50 \%$

Reduce time required for mechanical and operational adjustments by $50 \%$

Reduce packaging failures to $5 \%$ of non-scheduled stoppage

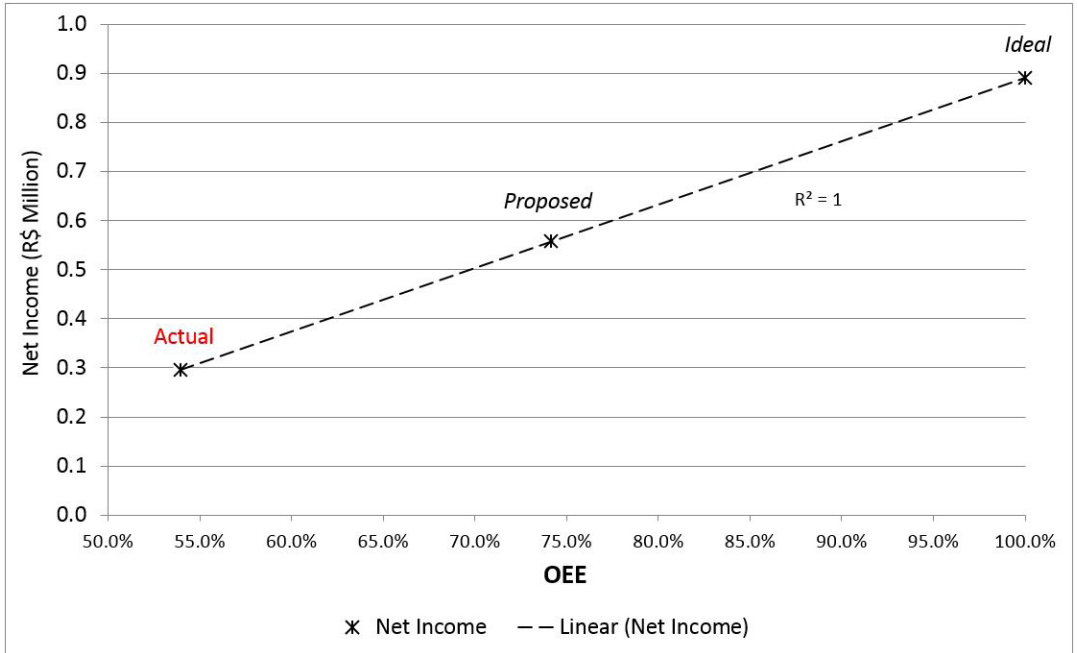

Figure 10. Monthly net income projection based on OEE improvement. 
Use of packing equipment efficiency as an estimate of the overall plant effectiveness and as a tool to improve financial results of a food-processing unit

Rodrigues, J. B. M.; Cabral, A. C. D.

projects the monthly net income (actual, proposed and ideal) for the plant based on proportionally unitized sales price, variable and fixed costs and considering similar Total Time for all three scenarios.

As shown in Figure 10 the 20.2 percent points improvement goal in OEE is expected to result in $88 \%$ net income increase and also projects the path of improved earnings.

\section{Conclusions}

The overall throughput of a production unit with equipment assembled in series can be estimated by calculating the OEE of the farthest equipment for the special approximation that all pieces of equipment are planned to run at the same speed as the slowest one (the system's constraint). In case of a food processing unit it is proposed that the OEE data shall be collected for the packing machine for it can unveil its own as well as upstream and downstream losses.

The so calculated OEE correlates with the net income generated by the factory. While the maximum output $\left(\mathrm{N}_{\text {max }}{ }^{\prime}\right)$, unit product price and variable cost, operating fixed cost, depreciation, taxes and interests remain constant along total time the net income and OEE present a linear correlation.

The analysis of the parameters Availability, Performance and Quality provide a valuable source of information to reveal the main losses occurring in the process. By evaluating the geometric properties of OEE it has been demonstrated that by acting on the parameter with the worst result the response on OEE is greater than when the other parameters are improved. This heuristic is to be considered by the plant effectiveness coordinators while planning improvement actions to the process.

The above conclusions were validated by calculating the OEE from data collected manually for the packing line in a food process factory. It was possible to identify the main causes of losses while evaluating OEE parameters and, therefore, plan a set of actions to improve the OEE results. Moreover it was possible to estimate the financial benefits resulted from incremental gains in overall equipment effectiveness. Such gains are achieved by freeing up hidden capacity and without the need of capital expenditure to acquire additional equipment. That is a powerful incentive for food factories to invest in continuous improvement programs.

\section{References}

BUSSO, C. M.; MIYAKE, D. I. Análise da aplicação de indicadores alternativos ao Overall Equipment Effectiveness (OEE) na gestão do desempenho global de uma fábrica. Produção, São Paulo, v. 23, n. 2, p. 205-225, 2013.

CASTRO, F. P.; ARAUJO, F. O. Proposal for OEE (Overall Equipment Effectiveness) indicator deployment in a beverage plant. Brazilian
Journal of Operations \& Production Management, Rio de Janeiro, v. 9, n. 1, p. 71-84, 2012. http://dx.doi.org/10.4322/ bjopm.2013.006.

COSTA, S. E. G; LIMA, E. P. Uses and misuses of the 'overall equipment effectiveness' for production management. In: IEEE INTERNATIONAL ENGINEERING MANAGEMENT CONFERENCE, 2002, Cambridge. Proceedings... Eindhoven: IEEE, 2002. p. 816-820. http://dx.doi.org/10.1109/IEMC.2002.1038543.

DE RON, A. J.; ROODA, J. E. Equipment effectiveness: OEE revisited. IEEE Transactions on Semiconductor Manufacturing, Eindhoven, v. 18, n. 1, p. 190-196, 2005. http://dx.doi.org/10.1109/ TSM.2004.836657.

ENAGHANI, M. R.; ARASHPOUR, M. R.; KARIMI, M. The relationship between lean and TPM. 2009. $44 \mathrm{f}$. Thesis (Master of Science), School of Engineering. University of Borås, Borås, 2009.

HANSEN, R. C. Eficiência global dos equipamentos. Porto Alegre: Bookman Companhia Editora, 2006. 264 p.

HUANG, S. H.; DISMUKES, J. P.; SHI, J.; SU, Q.; RAZZAK, M. A.; BODHALE, R.; ROBINSON, D. E. Manufacturing productivity improvement using effectiveness metrics and simulation analysis. International Journal of Production Research, Abingdon, v. 41, n. 3, p. 513-527, 2003. http://dx.doi.org/10.1080/0020754 021000042391.

HUANG, S. H.; DISMUKES, J. P.; SHI, J.; SU, Q.; WANG, G.; RAZZAK, M.A.; ROBINSON, D. E. Manufacturing system modeling for productivity improvement. Journal of Manufacturing Systems, Atlanta, v. 21, n. 4, p. 249-259, 2002. https://doi.org/10.1016/ S0278-6125(02)80165-0.

INVESTOPEDIA LIBRARY. Investopedia. New York: LLC, 2015. Accessed on: 1 June 2015. Available at: http://www.investopedia. com/terms/n/netincome.asp

JACOBS, J. H.; ETMAN, L. F. P.; VAN CAMPEN, E. J. J.; ROODA, J. E. Characterization of operational time variability using effective process times. IEEE Transactions on Semiconductor Manufacturing, Eindhoven, v. 16, n. 3, p. 511-520, 2003. http:// dx.doi.org/10.1109/TSM.2003.815215.

MUCHIRI, P.; PINTELON, L. Performance measurement using overall equipment effectiveness (OEE): literature review and practical application discussion. International Journal of Production Research, Abingdon, v. 46, n. 13, p. 3517-3535, 2008. http://dx.doi.org/10.1080/00207540601142645.

POMORSKI, T. Managing Overall Equipment Effectiveness [OEE] to optimize factory performance. In: IEEE INTERNATIONAL SYMPOSIUM ON SEMICONDUCTOR MANUFACTURING CONFERENCE, 1997, San Francisco. Proceedings... Eindhoven: IEEE, 1997. p. 33-36. http://dx.doi.org/10.1109/ISSM. 1997.664488.

TSAROUHAS, P. Implementation of total productive maintenance in food industry: a case study. Journal of Quality in Maintenance Engineering, United Kingdon, v. 13, n. 1, p. 5-18, 2007. http:// dx.doi.org/10.1108/13552510710735087. 